\title{
METHODOLOGICAL APPROACHES TO ASSESSING INSTITUTIONAL RESOURCES OF INNOVATIVE DEVELOPMENT OF RURAL TERRITORIES
}

\author{
Tatjana Tambovceva ${ }^{1}$, Maria Tereshina $^{2}$, Inna Miroshnichenko ${ }^{2}$ \\ ${ }^{1}$ Riga Technical University, Latvia; ${ }^{2}$ Kuban State University, Russia \\ tatjana.tambovceva@rtu.lv, mwstepanova@mail.ru,mirinna78@mail.ru
}

\begin{abstract}
The long-term sustainable development of rural areas determines the need to establish new development management models, based on a comprehensive analysis and assessment of development resources, taking into account the characteristics of specific territories. The aim of the study is to identify and operationalize institutional resources of the innovative development of rural areas, as well as the development of high-quality methods for monitoring and evaluation. The research methodology integrates traditional economic methods for collecting quantitative, sociological (expert) methods, as well as methods of economic statistics. The article highlights the key features of scientific discourse in the field of innovative development of rural territories, considers the main types of institutional resources, as well as existing approaches to their assessment. An analytical toolkit for monitoring and evaluating the institutional resources of the innovative development of rural territories is proposed, which allows diagnosing the range of efficiency of using the institutional resources of rural development, as well as determine the "scenario" of the institutional design of innovative development in relation to a specific rural territory. An institutional model for the innovative development of rural areas has been developed, which is a combination of five main subsystems, as well as indicators for evaluating each subsystem and the factors that influence it. It is proved that the success of achieving the goals of innovative development of rural territories is determined by the correspondence of the mechanisms of development of institutional resources and innovations (technological, organizational, marketing), as well as their focus on the long-term effects of sustainable development. Based on empirical research, the integrating role of "green" innovations as "growth points" for the sustainable development of rural territories is proved.
\end{abstract}

Keywords: rural, regional, innovative development, methodological approach, institutional resources.

\section{Introduction}

Cities will continue to play a key role in the 21st century innovative economy [1]. Nevertheless, both the recent socio-political and research discourse are increasingly concentrating on innovative processes that can become drivers of sustainable development of rural territories. Thus, the WIPO Report [2] is dedicated to the best innovative practices in the agricultural sector and promising innovative models and processes of rural development.

The OECD Policy Note "Rural 3.0. A framework for rural development" [3] emphasizes that in the near future rural areas will be able to play an important role in the implementation of key global opportunities and challenges. This includes, for example, developing new energy sources, solving climate challenges, innovation in food production and provision of natural resources to the growing population that will enable the transition to a new technological revolution.

Some researchers [4] identify some of the key economic and technological trends as incentives for innovative economic development of rural areas. Firstly, the authors are talking about strengthening public demand for "quality of life innovations". This includes healthy nutrition and organic products and services, which are considered to be traditional agricultural businesses. Secondly, rural dominant agriculture is diversified by the multifunctional economic use of natural resources, such as the production of non-food goods and various services. Thirdly, thanks to digitalization, rural areas are becoming less isolated and connected with urbanized areas, contributing to the "blurring" of the boundaries between the urban and rural type of economy. Thus, rural areas are becoming much more diverse and complex socio-economic systems. At the same time, approaches to the design of rural innovation systems are diverse, and the results of political and economic measures to support the development of rural areas actively developed and implemented in various countries are mixed.

Thekeytounderstandingandsystematizinginnovationprocessesinruralareascanbefoundintheliteratur edevotedtotheformationanddevelopmentofnational [5-7] and regional innovation systems [8;9], industry innovation [10], intra-company innovation [11] and urban innovation [12-15]. At the same time, specific socio-demographic, economic, environmental and cultural features of rural areas require 
a more detailed study of the ability of rural socio-economic systems to produce the type of knowledge, skills and experience necessary to create and effectively implement innovative activities.

The long-term sustainable development of rural areas requires new development management models. Such models are based on a comprehensive analysis and assessment of institutional development resources, taking into account the characteristics of specific territories. The aim of the study is to identify and operationalize the institutional resources of the innovative development of rural areas, as well as the development of high-quality methods for their monitoring and assessment.

\section{Materials and methods}

An interdisciplinary approach is the methodological basis of this study. It includes a comparative analysis of the scientific discourse on innovative systems at various levels of the hierarchy, analysis of studies, cases and statistical data on various aspects of the innovative development of rural territories. The empirical research technique integrates traditional economic methods for collecting quantitative data, sociological (expert) methods, as well as methods of economic statistics.

\section{Results and discussion}

In this study, the innovative development of rural areas is understood as the process of changes in the economic or social sphere of rural areas, adding factors of a new economic or social value to rural life.

Regarding the differentiation of the specific characteristics of rural innovation systems, it should be noted that the tendency to "blur" the differences between urban and rural economies, characteristic of the global digitalization process, "blur" the boundaries between urban and rural innovation systems. Moreover, some types of innovation are difficult to define as rural, urban or global. Advances in information and communications technology "open" rural markets and make them dependent on external competition factors. It strengthens incentives for innovation.

The transfer of implicit knowledge is also enhanced by the emergence of new opportunities to search for its sources and the development of a "remotely neutral" infrastructure that can be used regardless of the location of the recipient of services. In the general case, to classify innovations by their origin, one can use the matrix proposed by a number of researchers (Table 1). This matrix allows identifying and mapping problem areas for a comprehensive analysis of rural innovation policy.

Table 1

Types of innovations depending on the origin of supply and demand [4]

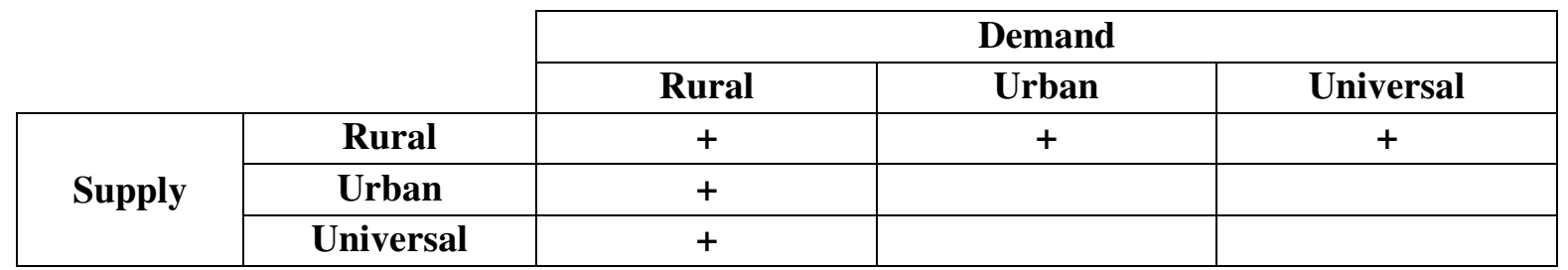

It should be noted that these types of innovations do not exist in isolation, but are closely linked by supply and demand and by the wider framework of regional and national innovation systems.

In fact, being an open system, a rural innovation system can be represented in the form of a "black box" model [16] that transforms resource flows at the "input" and "output". The internal institutional architecture of the system transforms resource flows, leading either to positive innovative effects (new goods and services, developed innovative competencies, new knowledge, managerial experience, technologies), or, in the case of institutional traps and barriers, to negative effects.

The institutional structure of the rural innovation system is in general a combination of business, scientific, educational, public, infrastructural and consumer subsystems, each of which is characterized by a specific set of innovative development resources and performs certain functions (Table 2).

The authors believe that the identified types of resources form the institutional structure of any territorial system (urban or rural). However, the quantity and quality of these resources are significantly different. 
Institutional Resources for Innovative Development of Rural Areas

\begin{tabular}{|c|c|c|}
\hline Institutional Subsystems & Resources & Functions \\
\hline $\begin{array}{l}\text { business enterprise sector (all } \\
\text { firms, organisations and } \\
\text { institutions producing sectoral } \\
\text { products, goods and services) }\end{array}$ & $\begin{array}{l}\text { investment and } \\
\text { financial resources; } \\
\text { material and } \\
\text { technical resources }\end{array}$ & $\begin{array}{l}\text { formation of investment demand for } \\
\text { innovative developments, their integration } \\
\text { into the sphere of production and services, } \\
\text { selection of the most viable innovations } \\
\text { and their commercialization }\end{array}$ \\
\hline $\begin{array}{l}\text { scientific and educational } \\
\text { sector (structures of academic } \\
\text { and applied science, higher } \\
\text { education organizations, } \\
\text { educational institutions of } \\
\text { higher education organizations) }\end{array}$ & $\begin{array}{l}\text { intellectual, HR, } \\
\text { material and } \\
\text { technical, } \\
\text { information } \\
\text { resources }\end{array}$ & $\begin{array}{l}\text { generation of knowledge to identify } \\
\text { priority areas for sustainable } \\
\text { development, development of human } \\
\text { resources, development of individual and } \\
\text { organizational innovative competencies }\end{array}$ \\
\hline $\begin{array}{l}\text { public sector (state authorities, } \\
\text { departmental structures of } \\
\text { executive bodies, budget funds, } \\
\text { rural development agencies) }\end{array}$ & $\begin{array}{l}\text { administrative, } \\
\text { fiscal, information } \\
\text { and discursive } \\
\text { resources }\end{array}$ & $\begin{array}{l}\text { setting priorities for socio-economic } \\
\text { development, developing institutional } \\
\text { mechanisms for innovations; } \\
\text { accumulation and distribution of } \\
\text { knowledge and technology }\end{array}$ \\
\hline $\begin{array}{l}\text { infrastructure sector (business } \\
\text { incubators, incubators of rural } \\
\text { initiatives, pilot production } \\
\text { facilities, collective use } \\
\text { centers) }\end{array}$ & $\begin{array}{l}\text { HR, logistical, } \\
\text { informational, } \\
\text { organizational and } \\
\text { service resources }\end{array}$ & $\begin{array}{l}\text { ensuring the connection between urban } \\
\text { and rural innovation systems, } \\
\text { coordinating supply and demand transfer } \\
\text { of innovations from science to production } \\
\text { and services, from one sector of the } \\
\text { economy to another; } \\
\text { creation of communication between the } \\
\text { subjects of innovation at various stages of } \\
\text { the creation and promotion of innovation; } \\
\text { organizational services for innovation }\end{array}$ \\
\hline $\begin{array}{l}\text { consumer sector (individual } \\
\text { and associated entities of the } \\
\text { external and internal consumer } \\
\text { market) }\end{array}$ & $\begin{array}{l}\text { financial resource, } \\
\text { information } \\
\text { resource, symbolic } \\
\text { resource }\end{array}$ & $\begin{array}{l}\text { creation of consumer demand for } \\
\text { innovations and their development in new } \\
\text { segments of the consumer market }\end{array}$ \\
\hline
\end{tabular}

The following problems are characteristic of the institutional structure of innovative resources of rural areas:

- weak economic base, low business density;

- few opportunities (in comparison with urban areas) to use external effects of new knowledge and innovative technologies;

- weak competitive environment to stimulate innovation;

- high transport costs, especially in remote rural areas;

- lack of innovation infrastructure;

- limited financial resources for investment in innovation, new technologies or the development of innovative products, which reduces the ability of rural economic agents to respond innovatively to regulatory pressure, turning it into additional business costs that threaten competitiveness;

- limited access to training and new knowledge;

- low efficiency of the "innovative elevator";

- poor coordination in the implementation of individual innovative mechanisms and programs;

- low level of network interaction between agents of innovative changes.

At the same time, in some cases, these typical rural problems can act as "strong" incentives and drivers for the development of innovative processes in rural areas. 
Moreover, the identification of specific resources of innovative development of rural areas is characterized by a high degree of uncertainty, since the actual use of resources for a specific rural area largely depends on the institutional context for the implementation of innovative activities, as well as the time lag between the formation of demand for a specific resource in the short and long term.

Therefore, the empirical identification of the resources of each of the institutional subsystems of the rural innovation system, as well as the development of high-quality monitoring methods and a comprehensive assessment of its institutional sustainability, is of great importance.

The authors propose a monitoring approach in which the institutional model of a rural innovation system is a combination of five main subsystems. Four groups of factors have a "cross-cutting" effect on the institutional sustainability and effectiveness of each of these five subsystems. The authors list the indicators in the following matrix in order to ensure comprehensiveness (Table3).

Table 3

Matrix for assessing the priorities of institutional sustainability of subsystems of the regional innovation system (compiled by the authors)

\begin{tabular}{|c|c|c|c|c|}
\hline \multirow{2}{*}{$\begin{array}{c}\text { Institutional } \\
\text { Subsystems }\end{array}$} & Economic & Social & $\begin{array}{c}\text { Policy and } \\
\text { Regulatory }\end{array}$ & $\begin{array}{c}\text { Environmental and } \\
\text { Resource }\end{array}$ \\
\cline { 2 - 5 } & $\mathrm{S} 1 \mathrm{~B} 1$ & $\mathrm{~S} 1 \mathrm{~B} 2$ & $\mathrm{~S} 1 \mathrm{~B} 3$ & $\mathrm{~S} 1 \mathrm{~B} 4$ \\
\hline $\begin{array}{c}\text { Business enterprise } \\
\text { sector }\end{array}$ & $\mathrm{S} 2 \mathrm{SC} 1$ & $\mathrm{~S} 2 \mathrm{SC} 2$ & $\mathrm{~S} 2 \mathrm{SC} 3$ & $\mathrm{~S} 2 \mathrm{SC} 4$ \\
\hline $\begin{array}{c}\text { Scientific and } \\
\text { educational sector }\end{array}$ & $\mathrm{S} 3 \mathrm{P} 1$ & $\mathrm{~S} 3 \mathrm{P} 2$ & $\mathrm{~S} 3 \mathrm{P} 3$ & $\mathrm{~S} 3 \mathrm{P} 4$ \\
\hline Public sector & $\mathrm{S} 4 \mathrm{I} 1$ & $\mathrm{~S} 4 \mathrm{I} 2$ & $\mathrm{~S} 4 \mathrm{I} 3$ & $\mathrm{~S} 4 \mathrm{I} 4$ \\
\hline Infrastructure sector & $\mathrm{S} 5 \mathrm{CO} 1$ & $\mathrm{~S} 5 \mathrm{CO} 2$ & $\mathrm{~S} 5 \mathrm{CO} 3$ & S5CO4 \\
\hline Consumer sector & &
\end{tabular}

Each of the matrix cells is a set of indicators selected and verified using the methods of qualitative analysis (in-depth expert interviews and case study methods). So, for example, the influence of the environmental-resource factor of institutional sustainability on each of the subsystems was evaluated by the following indicators: S1B4 - Development of goods and services for environmental protection; S2SC4 - The level of creation of new knowledge in the field of environmental protection and rational nature management; S3P4 - Environmental quality and potential for improvement; S4I4 - The potential for environmental modernization of production and housing infrastructure; $\mathrm{S} 5 \mathrm{CO} 4-$ The degree of formation of the social request for benefits associated with environmental innovation.

As an object of empirical research, the authors selected 7 typical rural areas of Krasnodar Krai with similar natural resource, socio-economic and demographic characteristics. Evaluation of each component of the matrix was carried out using expert assessments, ranked at three intervals of a 100point scale and included two projections: the current state of institutional stability of the rural innovation system ("what is") and the target, reference state ("what should be"). Various institutions of innovative development were evaluated in order to assess the internal structure of the institutional components of the rural innovation system. Potential "drivers" were identified and classified (GAP analysis method) to ensure the successful production and acceleration of innovative practices within the innovation system of rural territories. Then their current state was characterized. The reliability of the consistency of expert assessments was verified by the method of positional analysis and showed an acceptable and high degree of consistency.

Using the toolkit developed by the authors, empirical profiles of the institutional sustainability of subsystems of rural innovation systems have been compiled (Figure1) and the most significant institutions and resources from the point of view of the need for their development were identified.

The identification of green innovations as integrating "growth points" for the "production" and acceleration of innovations based on technological and non-technological changes in rural areas is an interesting result of empirical research. This can be seen in the scatter diagrams (Fig. 2, 3), where both current and normative assessments of experts on the environmental resource component are significantly different from others. 


\section{S1 Business enterprise sector}

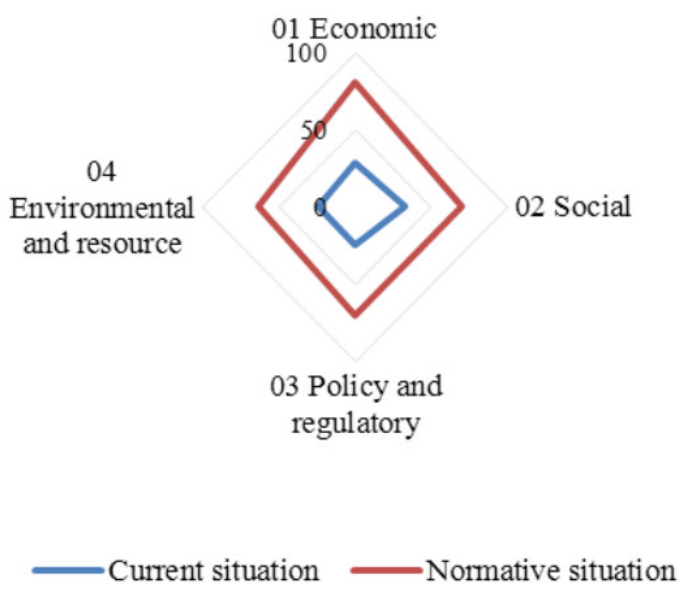

S3 Public sector

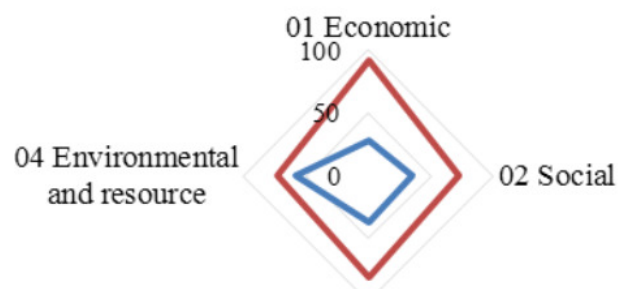

03 Policy and regulatory

\section{S2 Scientific and educational sector}

04

\section{Environmenta}

1 and resource

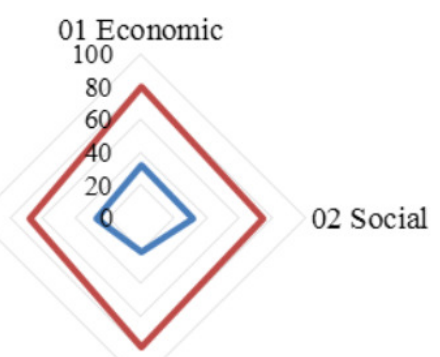

03 Policy and regulatory
Current situation $\longrightarrow$ Normative situation

\section{S4 Infrastructure sector}

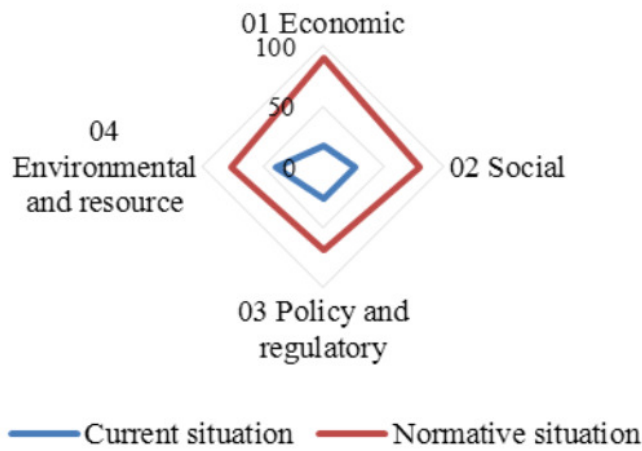

\section{S5 Consumer sector}

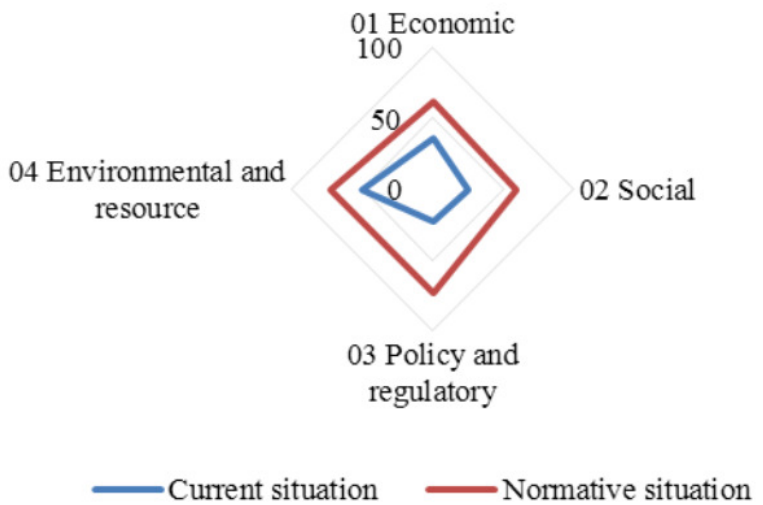

Fig. 1. Empirical profiles of the institutional sustainability of subsystems of rural innovation systems

The authors believe that updating the environmental factor in the development of rural innovation systems as a new quality of their innovative development requires additional study in the context of resource support of incremental innovations with the effect of decoupling.

This is especially important for rural areas, the development of which is closely related to the quantity and quality of natural resources. As well as systemic innovations that are capable of forming entire networks of actors and complexes of transformations in the organizational and institutional mechanisms of rural development. 


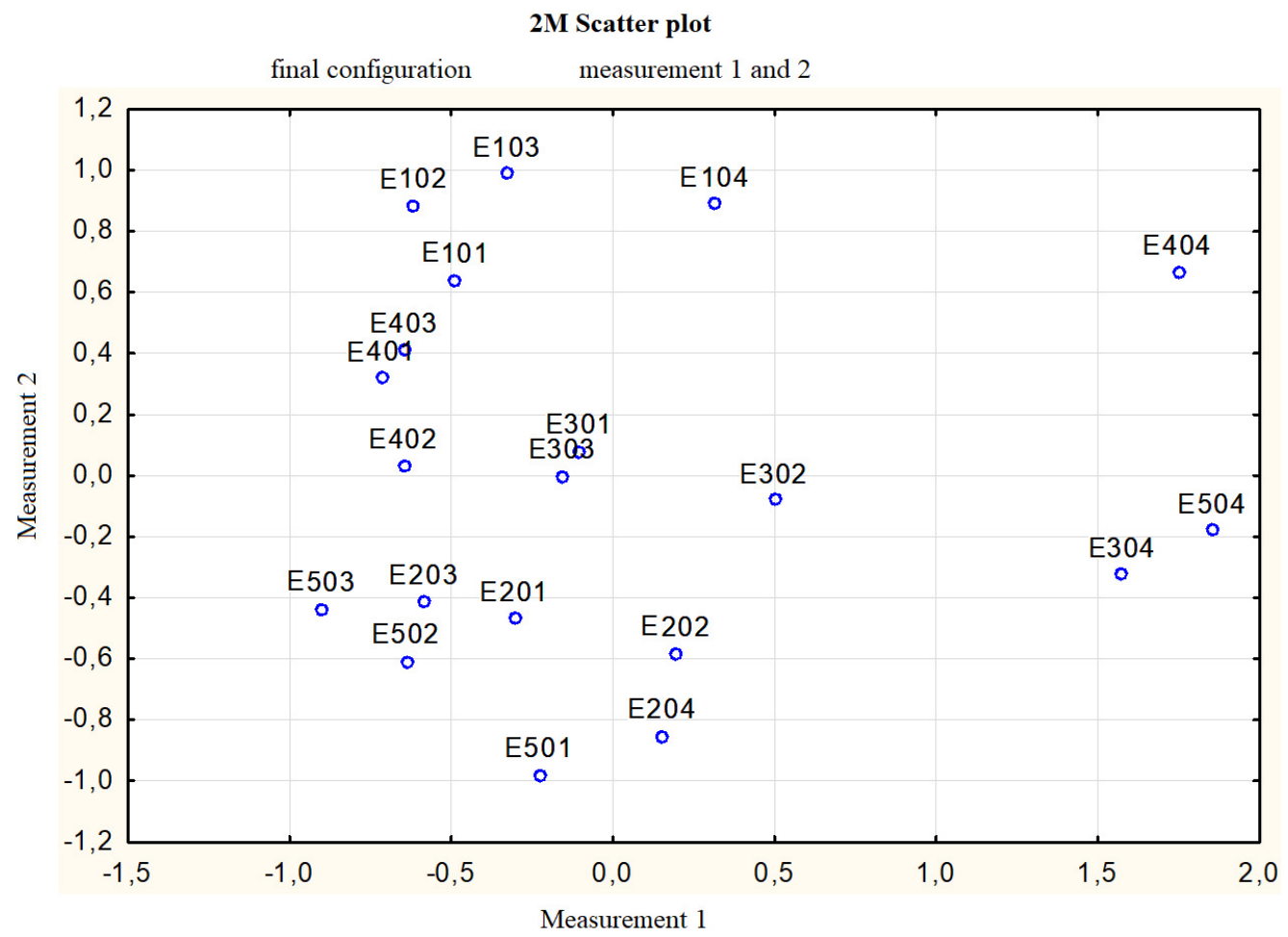

Fig. 2. Scatter plot - current estimates

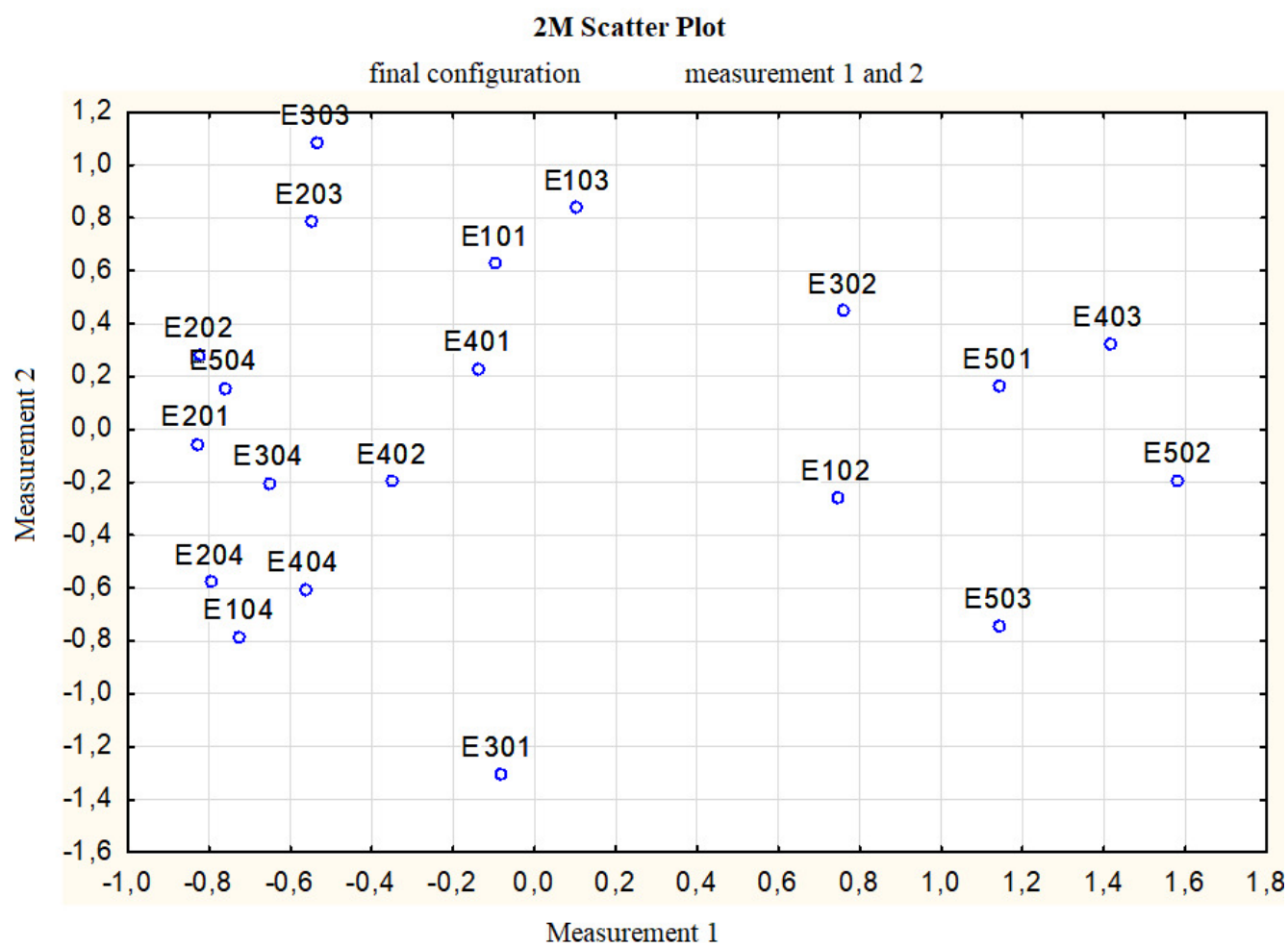

Fig. 3. Scatter plot - normative estimates

\section{Conclusions}

1. Currently, research discourse is increasingly focusing on innovative processes that can become drivers of sustainable rural development. However, approaches to the design of rural innovation systems are diverse, and the results of political and economic measures to support the development of rural areas vary significantly. The long-term sustainable development goals of rural areas determine the need to develop new management models based on a comprehensive 
analysis and assessment of institutional development resources, taking into account the specifics of certain territories.

2. The institutional structure of the rural innovation system is in general a combination of business, scientific, educational, public, infrastructural and consumer subsystems. Each of these subsystems is characterized by a specific set of innovative development resources and performs certain functions. The identification of specific resources for the innovative development of rural areas is characterized by a high degree of uncertainty, since their actual benefits for a specific rural area largely depend on the institutional context for the implementation of innovative activities, as well as the time lag between the formation of demand for a specific resource in the short- and longterm period.

3. The authors propose a specific approach for monitoring the availability and effectiveness of the use of institutional resources for rural development. Here the institutional model of a rural innovation system is a combination of five main subsystems. Four groups of factors have a "cross-cutting" effect on the institutional sustainability and effectiveness of each of these five subsystems. The factors are the following: economic, social, political and regulatory, and environmental and resource.

4. The methodology for assessing the institutional resources of innovative rural development was developed and tested in 7 typical rural areas with close natural resource, socio-economic, demographic characteristics. Using the toolkit developed by the authors, empirical profiles of the institutional sustainability of subsystems of rural innovation systems have been compiled and the most significant institutions and resources from the point of view of the need for their development were identified.

5. Updating the environmental factor requires considering the eco-innovative component in the formation and implementation of innovative rural development strategies as an important competitive advantage.

\section{References}

[1] World Intellectual Property. Report 2019. The Geography of Innovation: Local Hotspots, Global Networks. [online] [3.03.2020]. Available at: https://www.wipo.int/edocs/pubdocs/en/wipo_pub_944_2019.pdf

[2] The Global Innovation Index 2017Innovation Feeding the World. [online] [10.03.2020]. Available at: https://www.wipo.int/edocs/pubdocs/en/wipo_pub_gii_2017.pdf

[3] Rural 3.0. A framework for rural development. OECD 2018. [online] [10.03.2020]. Available at: https://www.oecd.org/cfe/regional-policy/Rural-3.0-Policy-Note.pdf

[4] Mahroum S., Atterton J., Ward N., Williams A.M., Naylor R., Hindle R., Rowe F. Rural Innovation. 2007. [online] [10.03.2020]. Available at:

https://media.nesta.org.uk/documents/rural_innovation.pdf

[5] Freeman C. Technology and Economic Performance: Lessons from Japan. London: Pinter, 1987. [online] [10.03.2020]. Available at: https://trove.nla.gov.au/work/12880642.

[6] Lundvall B.-A. Why study national systems of innovations and national styles of innovation // Technology Analysis and Strategic Management, 10(4), 1998, pp.407-421. DOI: $10.1080 / 09537329808524324$

[7] Nelson R. National Innovation Systems. A Comparative Analysis. New York/Oxford: Oxford University Press, 1993.

[8] Cook P. Regional innovation system: concepts, analysis, and typology. In: RESTPOR 96: global comparison of regional RTD and innovation strategies for development and cohesion. Working paper, European commission, Brussels, 1996.

[9] Cook P. Regional Innovation Systems, Clean Technology \& Jacobian Cluster-Platform Policies. Regional Science Policy \& Practice, vol. 1, 2008, pp. 23-45. DOI: 10.1111/j.17577802.2008.00002.x

[10] Malerba F. Sectoral systems of innovation and production/ Research Policy. vol. 31, issue 2, February 2002, pp. 247-264.

[11] Chen J., Huang S., Xu Q. Firm innovation systems: perspectives of researches on state-owned key enterprises. Front. Eng. Management, vol. 2, issue 1, 2015, pp. 64. 
[12] Markatou M., Alexandrou E. Urban system of innovation: main agents and main factors of success. Procedia Social Behaviour Science, vol. 195, 2015, pp. 240-250.

[13] Wong, C.-Y., Ng, B.-K., Azizan, S.A., Hasbullah, M.. Knowledge structures of city innovation systems: Singapore and Hong Kong. J. Urban Technol. 25 (1), 2018, pp. 47-73

[14] Zhao, L., Li, Z. The study of the city innovation system's dynamical rules. Stud. Sci. Sci. 21 (01), 2003, pp. 71-100.

[15] Zygiaris, S. Smart city reference model: assisting planners to conceptualize the building of smart city innovation ecosystems. J. Knowl. Econ. 4 (2), 2013, pp. 217-231

[16] Chistjakova N.O. Региональная инновационная система: модель, структура, специфика (Regional innovation system: model, structure, specificity). Innovacii. - 2007. - № 4. pp. 55-58. (In Russian). 